\title{
Late Tithonian Ammonites from Chia Gara Formation at Maten Anticline, Northern Iraq
}

\author{
Mohammed W. Al-Abbasi \\ Dams and Water \\ Resources center \\ University of Mosul
}

\author{
Majid M. Al-Mutwali \\ Department of Geology \\ College of Science \\ University of Mosul
}

Nabil Y. Al-Banna

Petroleum and Mining

Engineering College

University of Mosul

(Received 3/12/2013 , Accepted 3/6/2014)

\begin{abstract}
The present study included identification and systematic description of some ammonites from the upper part of Chia Gara Formation, on the southern limb of Maten anticline at Amadia area, northern Iraq. Six species belong to five genera and three families were described. The two species; Berriasella privasensis and Parodontoceras calistoides were previously identified, and four species were left under open nomenclature, due to bad preservation and lack of material, these are; Parodontoceras sp., Spiticeras (Kilianiceras) sp., Substeueroceras sp. and Haploceras sp.

The studied ammonites occur as an assemblage fauna in the Durangites Zone, which indicates Late Tithonian age for the upper part of Chia Gara Formation in the Amadia area.

Keywords: Tithonian, Ammonites, Chia Gara Formation, Maten anticline.

$$
\begin{aligned}
& \text { آمونايت التيثوني المتأخر لتكوين جياكارا في طية متين، شمال العراق } \\
& \text { نبيل يوسف البنا } \\
& \text { ماجد مجدي المتولي } \\
& \text { محمد وليد العباسي } \\
& \text { كلبة هندسة النفط والتعدين } \\
& \text { قسم علوم الارض مجاي العندي } \\
& \text { مركز بحوث السدود }
\end{aligned}
$$

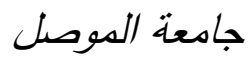

$$
\begin{aligned}
& \text { كلية العلوم } \\
& \text { والموارد المائية } \\
& \text { جامعة الدوصل العلم } \\
& \text { جامعة الموصل } \\
& \text { الملخص }
\end{aligned}
$$$$
\text { تتضمن الدراسة الحالية تثخيص ووصف بعض متحجرات الأمونايت من الجزء العلوي لتكوين جياكارا }
$$$$
\text { ضمن الطرف الجنوبي لطية منين في منطقة العمادية، شمال العراق. اشتملت حشود الأمونايت الموصوفة لأنية }
$$ 
في الدراسة الحالية على ستة انوع تابعة لخمسة اجناس وثلاثة عوائل، اثثان منهم موصوفين سابقا: بarodontoceras calistoides و Berriasella privasensis بسبب رداءة الحفظ وقلة عدد العينات وهم:

Substeueroceras sp., Spiticeras (Kilianiceras) sp., Parodontoceras sp., Haploceras sp.

$$
\begin{aligned}
& \text { تتواجد هذه الحشود الموصوفة ضمن نطاق Durangites الدال على التيثوني المتأخر • وعليه فان } \\
& \text { الجزء العلوي لتكوين جياكارا في منطقة العمادية يمتل التيثوني المتأخر . } \\
& \text { الكلمات الدالة: التيثوني، الأمونايت، تكوين جياكار ا، طية متين. }
\end{aligned}
$$

\section{INTRODUCTION}

The studied section is located at the southern limb of Maten anticline, about $(2 \mathrm{~km})$ northeastern Amadia area. The midpoint of the section at $\left(37^{\circ} 06^{\prime} 30^{\prime \prime} \mathrm{N}\right)$ Latitude and $\left(43^{\circ} 30^{\prime} 33^{\prime \prime} \mathrm{E}\right)$ Longitude.

Maten anticline is asymmetrical fold, lying East - West trend within the high folded zone of the unstable shelf (Jassim and Buday, 2006), the southern limb is steeper than the northern limb, (Fig. 1).

The Chia Gara Formation (M. Tithonian-Berriasian) was first defined by Wetzel (1950 in Bellen et al., 1959) at the Chia Gara anticline, south of Amadia town in the high folded zone of north Iraq. The formation at its type locality is $232 \mathrm{~m}$ thick, it is composed of unbroken succession of thin bedded limestone and shales, containing rich ammonite faunas, grading upwards to yellowish marly limestone and shale with a zone of bullion beds, $21 \mathrm{~m}$ thick at the base (Bellen et al., 1959). The studied section is composed about $90 \mathrm{~m}$ thick of alternation beds of pale to dark brown shale and white-yellowish limestone (the lithological description of the studied section is shown in (Fig. 2). The lower boundary is sharp between the tough dolostone of Barsarin Formation (Late Kimmeridgian) and thin bedded limestone of Chia Gara Formation, without any indication of unconformable evidences. The upper boundary is unconformable with the overlying Sarmord Formation (Valanginian), indicated by thin beds of conglomerate.

The previous studies of ammonites in Chia Gara Formation carried out by Spath (1950) was done on the identification and description of new Tithonian ammonites in this formation. Howarth (1992) gave a detailed paleontological study of ammonites zonation in two section (Banki and Chia Gara areas) of Chia Gara Formation. Leanza (1996) studied The Tithonian ammonite Genus Chigaroceras in Chia Gara Formation as a bioevent marker between the western Tethyan and the Andean realms.

The aim of the present study is to identify and describe ammonite fauna from Chia Gara Formation (Fig. 2), in order to obtain the age of the studied section. 


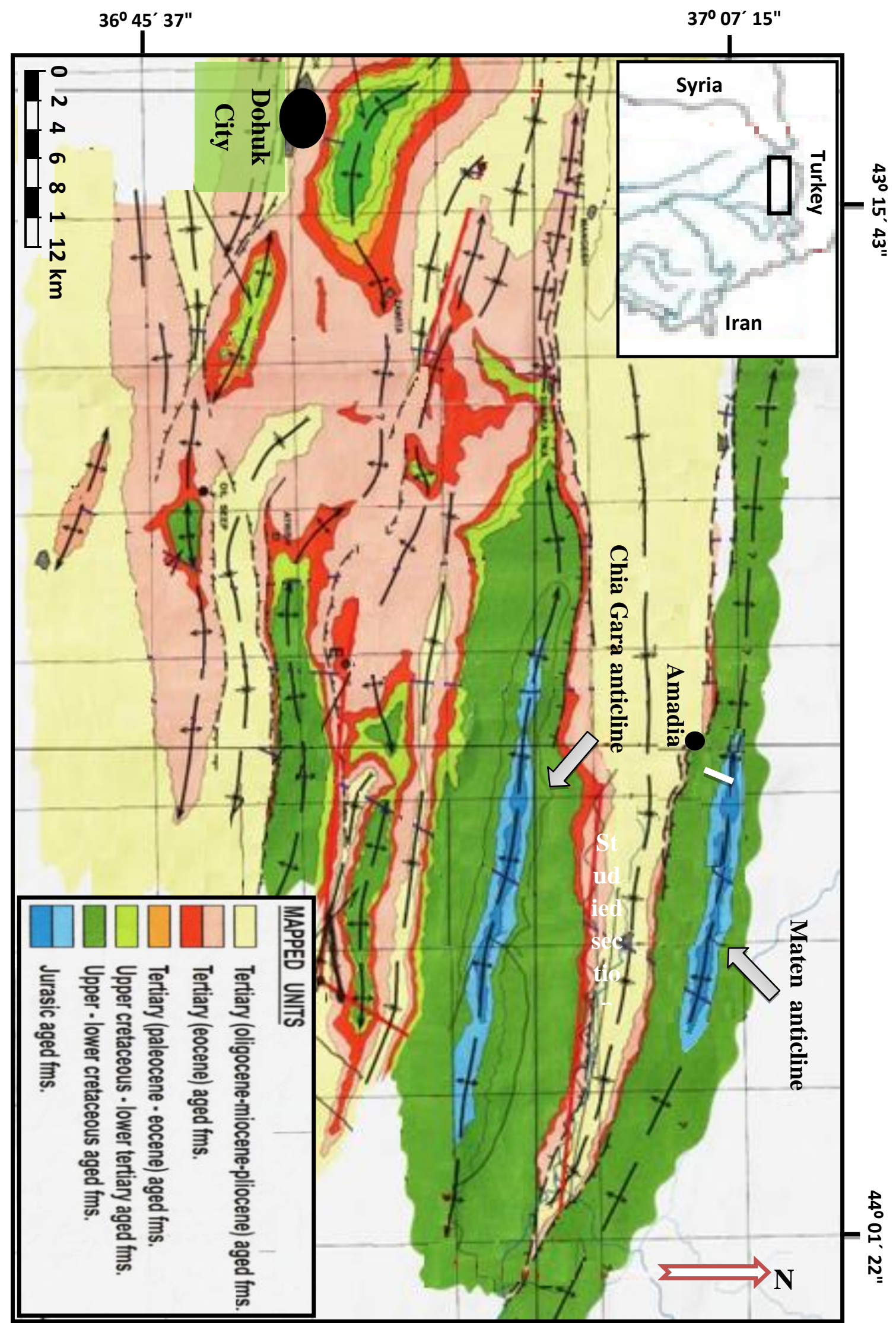

Fig. 1: Geological Map with Indication to the Studied Section, Modified from (Merty Energy Company, 2004). 


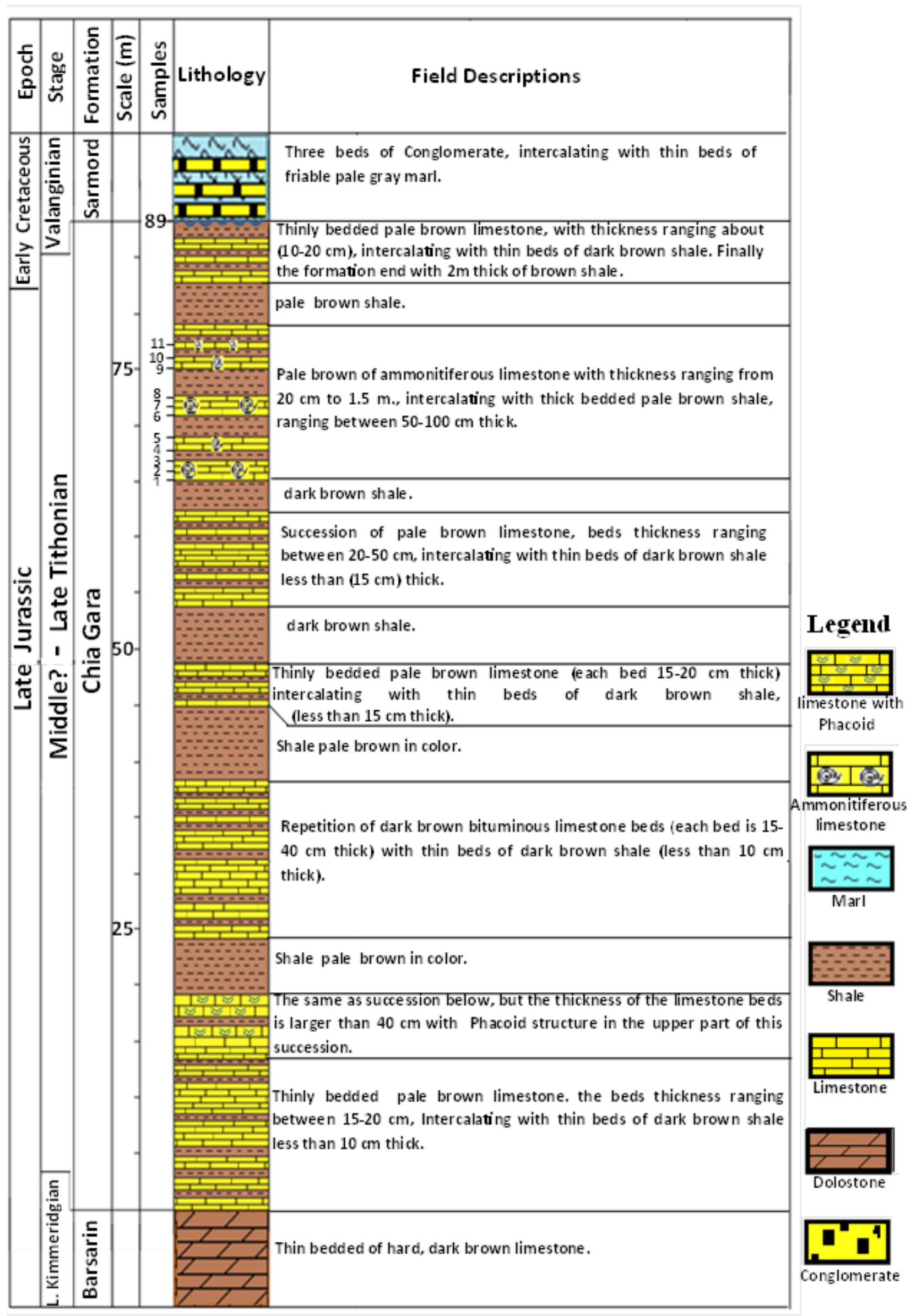

Fig. 2: Lithological section of Chia Gara Formation, at southern limb of Maten anticline 


\section{Systematic Description}

The identification of the Ammonite fauna in the current study which is moderately to well preserved at several horizons in the upper part of the section, at the interval (65-77m), were mainly depended on Spath (1950), Spath (1952), Imlay and Jones (1970), Pszczolkowski and Myszynski (2004) and Vašiček (2010). This study used Moore (1957) for classification of the species.

Six species belonging to five genera and three families were described by using their external shell features and parameter's: shell diameter (D), umbilicus diameter $(\mathrm{u})$, whorl height $(\mathrm{H})$ and the ratio of umbilicus diameter to shell diameter (see sketch diagram Fig. 3).

The synonyms references which are not mentioned in the references list were cited by Leanza (1945), Khimchiachvili (1987) and Parent et al. (2011).

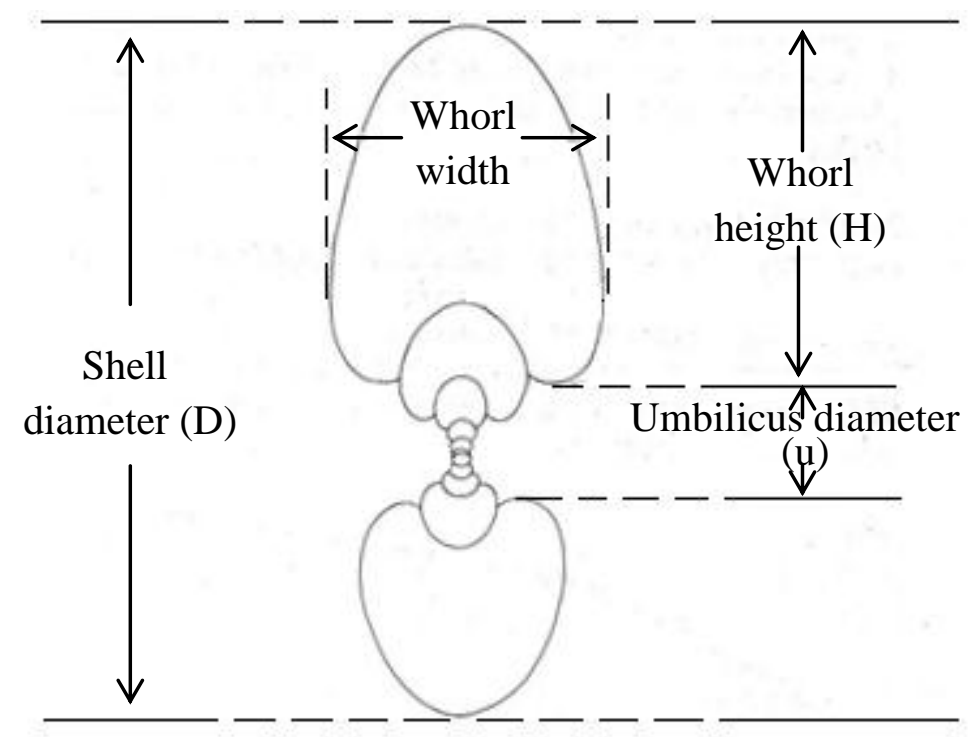

Fig. 3: Schematic Diagram of the Ammonite shell, Modified from (Murray, 1985).

\section{Depositary}

All the studied species were deposited in the Mosul University, Department of Geology, lab number (201), under the specimens numbers (1-11).

Phylum: MOLLUSCA

Class: CEPHALOPODA Leach, 1817

Order: AMMONOIDEA Zittel, 1884

Suborder: AMMONITINA Hyatt 1889

Superfamily PERISPHINCTOIDEA Steinmann, 1890 
Family: OLCOSTEPHANIDAE Haug, 1910

Genus: Spiticeras Uhlig, 1903

Subgenus: Kilianiceras Djanelidze, 1922

Type species: Ammonites spitiensis Blanford, 1864

Diagnosis: Planispiral, evolute, ornamentation characterized by numerous coarse ribs in the last whorl, in addition to some tubercles in the moderate whorl.

\section{Spiticeras (Kilianiceras) sp.}

(Plate 1, Fig. A)

Studied material: One cast specimen, sample number 11.

Description: Planispiral, partially evolute, shell dimensions are $\mathrm{D}=56 \mathrm{~mm}$, $\mathrm{u}=15 \mathrm{~mm}$ and $\mathrm{H}=21 \mathrm{~mm}$, umbilicus deep and wide, the ratio of the umbilicus diameter to the shell diameter about $27 \%$. The body chamber is unclear, and the phragmocone is inflated cone. The outer whorls of this ammonite bear fairly strong, radially trending primary ribs that divide into two ribs on the upper part of the flanks, (Bifurcate) and some tubercles in the moderate whorl.

Occurrence: The subgenus is described by Moore (1957) from late Tithonian to Berriasian, while it is described in the Berriasian age from the northwestern California and southwestern Oregon by Imlay and Jones (1970). Furthermore, this subgenus is recorded in Tithonian age by Spath (1950) from Chia Gara Formation in northern Iraq. In this study, the authors recorded it in the upper part of Chia Gara Formation.

Family: BERRIASELLIDAE Spath, 1922

Subfamily: BERRIASELLINAE Spath, 1922

Genus: Barriasella Uhlig, 1905

Type species: Ammonites privasensis Pictet, 1867

Diagnosis: This genus is characterized by having Planispiral compressed shell, and numerous bifurcating inclined coarse ribs.

Berriasella privasensis (Pictet, 1867)

(Plate 1, Figs. B and C)

1867 Ammonites privasensis Pictet, p. 84, p. 18, Fig. 1 a - b, Fig. 2.

1973 Berriasella privasensis (Pictet)- Hegarat, p.61, Fig. 3 - 9

1976 Berriasella privasensis (Pictet)- Khimchiachvili, p.84, Fig.1 - 3.

1982 Berriasella privasensis (Pictet)-Nikolov, p. 57, Fig. 2 - 4.

1987 Berriasella privasensis (Pictet)-Khimchiachvili, p.377, pl. 1, Fig. 4. 
Studied material: Tow cast specimen, samples number 3 and 7.

Dimensions:

\begin{tabular}{|c|c|c|c|}
\hline $\begin{array}{c}\text { No. of } \\
\text { Specimen (n) }\end{array}$ & $\begin{array}{c}\text { Shell diameter } \\
\text { (D) }\end{array}$ & $\begin{array}{c}\text { Umbilical } \\
\text { diameter (u) }\end{array}$ & $\begin{array}{c}\text { Whorl } \\
\text { height (H) }\end{array}$ \\
\hline 1 & 58 & 21 & 19 \\
\hline 2 & 48 & 16 & 15 \\
\hline Average & 53 & 19 & 17 \\
\hline
\end{tabular}

Description: Planispiral, evolute, average dimension is, $\mathrm{D}=53 \mathrm{~mm}, \mathrm{u}=19 \mathrm{~mm}$, $\mathrm{H}=17 \mathrm{~mm}$. The ratio of the umbilical diameter to the shell diameter about $36 \%$. The body chamber is moderate and coiled, the phragmocone compressed. There are about 18 strong inclined ribs on the half of the whorl. The most of them are bifurcate nearly above the middle of the whorl height. The anterior (adoral) one continues the direction of the primary rib, and the other branch is curved posteriorly, undivided ribs are also present. The incomplete inner cast is slightly deformed, but the ratio of dimensions and main characters of the sculpture allow us to assign this specimen to the species.

Occurrence: This species was firstly described by Pictet (1867), and it is identified from the late Tithonian by Spath (1952). On the other hand, it is recorded from Georgia in Berriasian age by Khimchiachvili (1987). Moreover, it identified in the late Tithonian age from the middle part of Chia Gara Formation, northern Iraq by Spath (1950) and Leanza (1996). In the current study, the species is recorded in the upper part of Chia Gara Formation.

Genus: Parodontoceras Spath 1923

Type species: Hoplites calistoides Behrendsen, 1891

Diagnosis: Planispiral, involute. The shell is sculptured by numerous fine inclined ribs, which form bifurcated in the end. 
Parodontoceras calistoides (Behrendsen, 1891)

(Plate 1, Figs. D, E)

1891 Hoplites calistoides Behrendsen, p. 402, Figs. 1a - 1b.

1897 Odontoceras calistoides (Behrendsen) -Stener, p. 41, Fig.13 - 16.

1923 Parodontoceras calistoides (Behrendsen) - Spath, p. 305.

1945 Parodontoceras calistoides (Behrendsen) - Leanza, p. 40, pl. V, Figs. 5, 6.

2011 Parodontoceras calistoides (Behrendsen) - Parent et al., p.54, Figs. 23A - B.

Studied material: Four cast specimen, samples number 1,4,5 and 9.

\section{Dimensions:}

\begin{tabular}{|c|c|c|c|}
\hline $\begin{array}{c}\text { No. of } \\
\text { Specimen (n) }\end{array}$ & $\begin{array}{c}\text { Shell diameter } \\
(\mathbf{D})\end{array}$ & $\begin{array}{c}\text { Umbilical } \\
\text { diameter (u) }\end{array}$ & $\begin{array}{c}\text { Whorl } \\
\text { height (H) }\end{array}$ \\
\hline$* 1$ & 29 & 8 & 9 \\
\hline$* 2$ & 41 & 10 & 13 \\
\hline 3 & 52 & 12 & 14 \\
\hline 4 & 53 & 12 & 15 \\
\hline Average & 44 & 11 & 13 \\
\hline
\end{tabular}

*photographed specimen.

Description: Planispiral, moderately involute, average dimension is $\mathrm{D}=44 \mathrm{~mm}$, $\mathrm{u}=11 \mathrm{~mm}, \mathrm{H}=13 \mathrm{~mm}$. Umbilicus slightly shallow, the ratio of the umbilical diameter to the shell diameter about $25 \%$. The body chamber is wide and uncoiled, the phragmocone is platycone. The external surface is well ornamented by numerous fine wavy ribs, in the inner part of the whorls. While it became gradational slightly strong in the last whorl and bifurcated before ends.

Occurrence: The present species was firstly recorded by Behrendsen (1891). In addition to this, it is described from Argentina in the late Tithonian by Leanza (1945) and from Northern Peruvian Andes by Enay et al. (1996), While it is described from Tithonian - Berriasian age by Parent et al. (2011). Locally, it is described in the late Tithonian from the middle part of Chia Gara Formation in 
northern Iraq by Spath (1950), Howrth (1992) and Leanza (1996). In the current study it is identified from Chia Gara Formation, particularly in the upper part.

\section{Parodontoceras sp.}

\section{(Plate 1, Fig. F)}

Studied material: One cast specimens, sample number 6.

Description: Planispiral, involute, ammonite dimension is $\mathrm{D}=41 \mathrm{~mm}$, $\mathrm{u}=13 \mathrm{~mm}, \mathrm{H}=12 \mathrm{~mm}$. Umbilicus slightly deep, the ratio of the umbilical diameter to the shell diameter about $32 \%$. The body chamber is wide and coiled, the phragmocone is platycone. The ornamentation is similar to these in the species $P$. calistoides, with more fine rather $P$. calistoides.

The present species resembles $P$. calistoides in the general shape and outline, but it differs in body chamber, which is coiled, rather than the uncoiled body chamber of $P$. calistoides. In addition to the ratio of the umbilical diameter to the shell diameter, which is large than of P. calistoides.

Occurrence: The current species was described from late Tithonian by Moore (1957), and it is identified in this study in the upper part of Chia Gara Formation.

Genus: Substeueroceras Spath, 1923

Type species: Odontoceras koeneni Steuer, 1897

Diagnosis: Planispiral, involute - moderately involute. Shell is ornamented by distinctive numerous fine wavy ribs, with very short distances.

\section{Substeueroceras sp.}

(Plate 1, Fig. G)

Studied material: Tow cast specimen, samples number 8 and 10 .

\section{Dimensions:}

\begin{tabular}{|c|c|c|c|}
\hline $\begin{array}{c}\text { No. of } \\
\text { Specimen (n) }\end{array}$ & $\begin{array}{c}\text { Shell diameter } \\
(\mathbf{D})\end{array}$ & $\begin{array}{c}\text { Umbilicus } \\
\text { diameter (u) }\end{array}$ & $\begin{array}{c}\text { Whorl } \\
\text { height }(\mathbf{H})\end{array}$ \\
\hline$* 1$ & 50 & 10 & 14 \\
\hline 2 & 41 & 9 & 10 \\
\hline Average & 46 & 10 & 12 \\
\hline
\end{tabular}

* photographed specimen. 
Description: Planispiral, moderately involute, average dimension are $\mathrm{D}=46 \mathrm{~mm}, \mathrm{u}=10 \mathrm{~mm}, \mathrm{H}=12 \mathrm{~mm}$. Umbilicus slightly deep, the umbilical wall is low. The ratio of the umbilicus diameter to the shell diameter about $22 \%$. The body chamber is crushed, the phragmocone is slightly inflated cone. The outer whorl overlaps about one-fourth of the preceding whorl. Before being crushed the specimen probably had a high subquadrate whorl section and flattened flanks. The venter is gently rounded. The ribs are fine, moderately spaced, and inclined gently forward on the flanks and are strongest on the venter. They are inflected slightly forward near the middle of the flanks and are arched gently forward on the venter. Some of the ribs are weakly swollen near the umbilicus. other ribs bifurcate at two levels. Many secondary ribs are indistinctly connected with the primary ribs. The ribs are not thinned along the midline of the venter.

The present species is fairly identical with the diagnostic features of the genus Substeueroceras, rather than the genus Parodontoceras, and it is described under open nomenclature due to the bad preservation of the material.

Occurrence: This species was described from late Tithonian by Leanza (1945) and Moore (1957), and it is distinguished in the current study in the upper part of Chia Gara Formation.

Superfamily: HAPLOCERATACEAE Zittel, 1884

Family: HAPLOCERATIDAE Zittel, 1884

Genus: Haploceras Zittel, 1870

Type Species: Amaltheus elimatus Oppel, 1868

Diagnosis: This genus is distinguished by having a smooth shell and a large body chamber.

Haploceras sp.

(Plate 1, Fig. H)

Studied material: One cast specimen, sample number 2.

Description: Planispiral, involute, ammonite dimensions is $\mathrm{D}=42 \mathrm{~mm}, \mathrm{u}=13 \mathrm{~mm}$, $\mathrm{H}=16 \mathrm{~mm}$. Umbilicus wide and deep, the ratio of the umbilical diameter to the shell diameter about $31 \%$. The body chamber is wide and coiled, the phragmocone is inflated cone. External shell surface is smooth.

This species let under open nomenclature due to the lack of material.

Occurrence: The present species is described from Kimmeridgian - Tithonian by (Moore, 1957). Locally it is recorded in the current study from the upper part of the Chia Gara Formation northern Iraq. 


\section{Age determination}

Six species belonging to five genera and three families were identified in the current study. Two of them are previously described; Berriasella privasensis and Parodontoceras calistoides, and four species left under open nomenclature These are; Parodontoceras sp., Spiticeras (Kilianiceras) sp., Substeueroceras sp. and Haploceras sp.

Age determination of the studied samples is relied on the whole cephalopod fauna. The species $P$. calistoides is well located and ascribed to the upper part of the late Tithonian by (Leanza, 1945), (Howarth, 1992). (Enay et al., 1996) and (Leanza, 1996). Furthermore, Spath (1952, P. 25) mentioned that "the P. calistoides were known to occur both above and below the border line between the Jurassic and Cretaceous; but Leanza (1945) established the real range of $P$. calistoides at the top of Argentinian Jurassic, so that species clearly cannot be used as a zone fossil for the lower Berriasian". This revealed that the existence of this species in the current study indicate the upper Tithonian age.

Also Spath (1952, P. 25) stated that "Lombard and Coaz (1932) proposed a twenty meter zone between the Tithonian and Berriasian, characterized chiefly by $B$. privasensis and B. Calisto, this is natural; the former species has long been the zonal index for the highest zone in the Jurassic, the latter, as has just been shown in common in the lowest Cretaceous". Moreover, Howarth (1992) refer that the $P$. calistoides and B. privasensis, in addition to Spiticeras (Kilianiceras) sp., Substeueroceras sp. and Haploceras sp. represent the main assemblages of Durangites Zone, which indicate to late Tithonian age. Besides that, Leanza (1996, P. 455) cited that "Ammonites registered at Iraq in (Durangites zone, late Tithonian) are P. aff. calistoides and B. aff. Privasensis".

Substeueroceras is diagnostic at the top Jurassic beds in Mexico by Imlay (1939), in Argentina by Leanza (1945) and in general study by Moore (1957). Spiticeras range from the top of the Tithonian through the Berriasian but not so high (Djauélidzé, 1922; in Imlay and Jones, 1970). On the other hand, the Spiticeras (Kilianiceras) ranges from upper Tithonian to Berriasian by Moore (1957). Haploceras ranges from Kimmeridgian - Tithonian (Moore, 1957).

The studied ammonites represent the main assemblage fauna of Durangites Zone which had been previously recorded in Iraq by Howarth (1992) and Leanza (1996) corresponding late Tithonian age. Accordingly, all the biostratigraphic evidences of the studied ammonite indicated that the upper part of the Chia Gara Formation in Amadia area represents the late Tithonian age, while the lower part of the formation in the studied section had been registered as Middle Tithonian age according to the previous study at the type section (Bellen et al., 1959). 


\section{REFERENCES}

Enay, R., Barale, G., Jacay, J., and Jaillard E., 1996. Upper Tithonian Ammonites and Floras from the Chicama Basin, Northern Peruvian Andes. Geo. Research Forum Switzerland, Vol. 1 - 2, pp. 221 - 234.

Howarth, M. K, 1992. Tithonian and Berriasian Ammonites from the Chia Gara Formation in northern Iraq. Paleontology, Vol. 35, No. 3, pp. 597 - 655.

Imlay, R. W., 1939. Upper Jurassic Ammonites from Mexico: Geol. Soc. America Bull., Vol. 50, pp. 1 - 78.

Imlay, R. W. and Jones, D. L., 1970. Ammonites from the Buchia Zones in Northwestern California and Southwestern Oregon. Geological Survey Professional Paper, U. S. Govt. Printing Office, Washington, pp. 1 - 59.

Jassim, S.Z. and Buday, T. 2006: Tectonic framework, In: Jassim, S.Z. and Goff, J.C. (eds.), Geology of Iraq. Dolin, Prague and Moravian Museum, Brno, pp. 45 - 55.

Khimchiachvili, N. G.,1987. The Tithonian - Berriasian ammonites of Georgia and their distribution. Foss., Evol., Amb.. Atti II Conv. Int. F. E. A., Pergola, pp. 371 - 381.

Leanza, A. F., 1945 Ammónites del Jurásico Superior y del Cretáceo Inferior de la Sierra Azul, en la parte meridional de la provincia de Mendoza. Paleoto. Anales Museo de la plata (n.s.), No. 1, pp. 1 - 99.

Leanza, H. A., 1996. The Tithonian Ammonite Genus Chigaroceras Howarth (1992) as a Bioevent Marker Between Iraq and Argentina. Geo. Research Forum Switzerland, Vols. I - 2, pp. 451 - 458.

Merty Energy Company, 2004. Geological Map of Northern Iraq. Appendix 1.

Moore, R. C., 1957. Treatise on Invertebrate Paleontology. Part (L), Mollusca (4), N. Y. Geol. Soc. Amer., 490 p.

Murray, J. W., 1985. Atlas of Invertebrate Macrofossils, Longman Group Limited, UK., 244 p.

Parent, H., Scherzinger, A. and Schweiger, G., 2011. The Tithonian-Berriasian ammonite fauna and stratigraphy of Arroyo Cieneguita, Neuqén-Mendoza Basin, Argentina. Bolten del Instituto de Fisiografia y Geologia Vol. 79 - 81, pp. 21 - 94.

Pszczolkowski, A. and Myszynski, R., 2004. Ammonite-Supported Microfossil and Nannoconid Stratigraphy of the Tithonian-Hauterivian limestones in Selected Sections of the Branisko Succession, Pieniny Klippen Belt (Poland). Studia Geologica Polonica. Vol. 123, pp. 133 - 197.

Spath, L. F., 1950. Anew Tithonian Ammonoid Fauna from Kurdistan, Northern Iraq. British Museum Bulletin(Natural History), Geology, Vol. 1, No. 4, pp. 93 - 146. 
Spath, L. F., 1952. Additional Observation on the Invertebrate (chiefly Ammonites) of the Jurassic and Cretaceous of East Greenland. II. Some Infravalanginian Ammonites from Lindemans Fjord, Wollaston Foreland; with a Note on the Base of the Cretaceous. Meddel. ora Gronland, Bd. 133, No. 4, pp. 1 - 40.

Vašiček, Z., 2010. Early Cretaceous Ammonites from the Butkov Quarry (Manín Unit, Central Western Carpathians, Slovakia). Acta Geologica Polonica, Vol. 60, No. 3, pp. 393 - 415.

\section{PLATE 1}

Fig. A: Spiticeras (Kilianiceras) sp. Chia Gara Formation. Sample number 11.

Figs. B and C: Berriasella privasensis (Pictet, 1867). Chia Gara Formation. Sample numbers 3 and 7.

Figs. D and E: Parodontoceras calistoides (Behrendsen, 1891). Chia Gara Formation. Sample numbers 1 and 9.

Fig. F: Parodontoceras sp. Chia Gara Formation. Sample number 6.

Fig. G: Substeueroceras sp. Chia Gara Formation. Sample number 8.

Fig. H: Haploceras sp. Chia Gara Formation. Sample number 2. 
PLATE 1
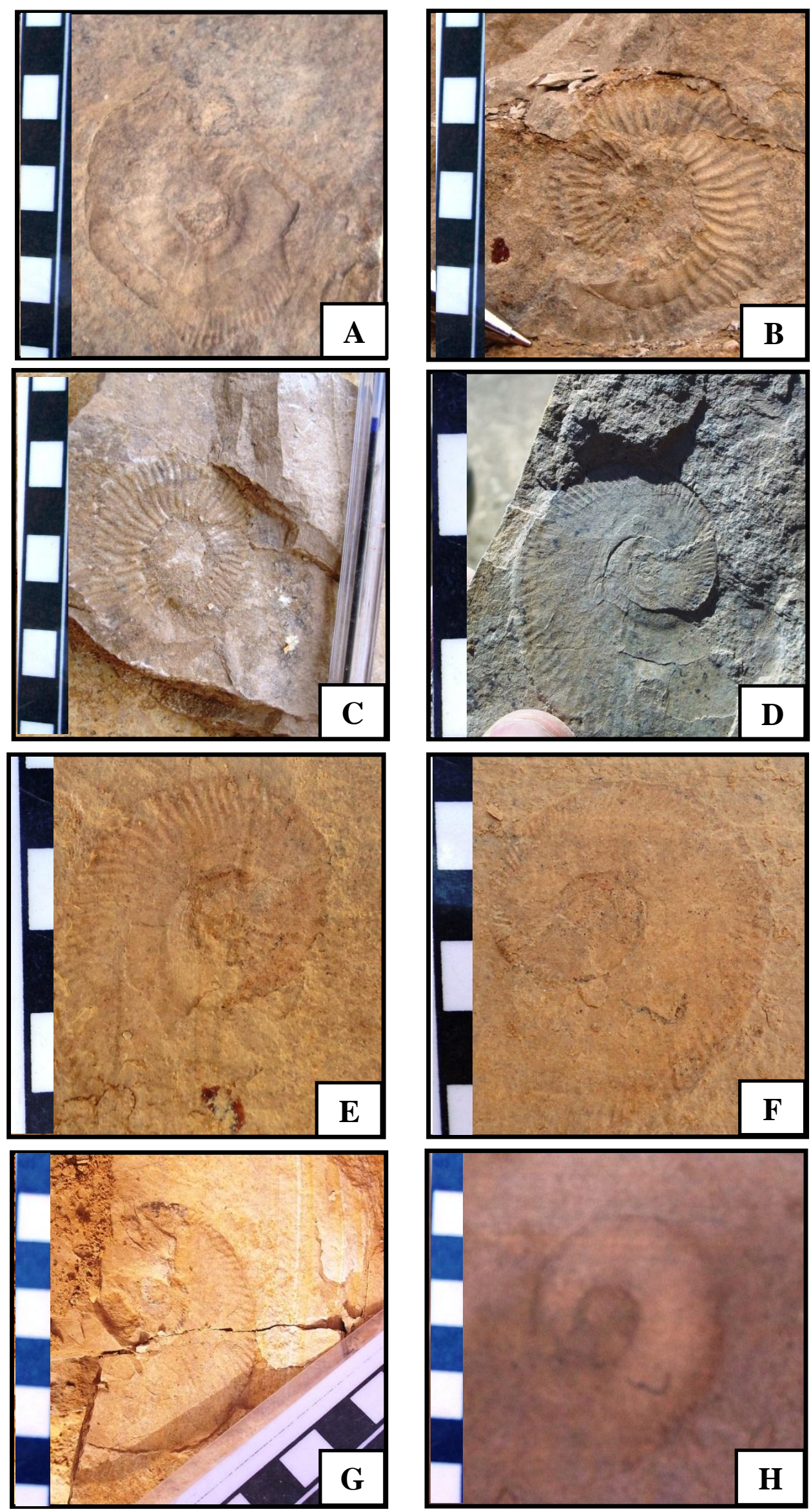

$1 \mathrm{bar}=1 \mathrm{~cm}$ 